\title{
Correlation between polymorphisms in the glucocorticoid receptor gene $N R 3 C 1$ and susceptibility to asthma in a Chinese population from the Henan Province
}

\author{
Z. Cheng ${ }^{1,2}$, L.L. Dai ${ }^{1,2}$, Q. Liu ${ }^{1,2}$, M. Liu ${ }^{1,2}$, Q. Wang ${ }^{1,2}$, P.F. Li ${ }^{1,2}$, H. Wang ${ }^{1,2}$, \\ L.Q. Jia ${ }^{1,2}$ and L. An ${ }^{1,2}$ \\ ${ }^{1}$ Respiratory and Critical Care Medicine, First Affiliated Hospital, \\ Zhengzhou University, Zhengzhou, China \\ ${ }^{2}$ Institute of Clinical Medicine, \\ The First Affiliated Hospital of Zhengzhou University, Zhengzhou, China \\ Corresponding author: Z. Cheng \\ E-mail: chengzhll_cz@163.com \\ Genet. Mol. Res. 15 (2): gmr.15028507 \\ Received January 28, 2016 \\ Accepted April 11, 2016 \\ Published June 3, 2016 \\ DOI http://dx.doi.org/10.4238/gmr.15028507
}

\begin{abstract}
The aim of this study was to investigate the association between four single nucleotide polymorphisms in NR3C1 (Tth111I, BclI, ER22/23EK, and N363S), which encode the glucocorticoid receptor, and asthma susceptibility in patients from the Henan Province of China. Three hundred and twenty-eight patients with asthma and 60 healthy volunteers were recruited to this study. The target SNPs were genotyped by polymerase chain reaction (PCR)-high resolution melting and PCR-restriction fragment length polymorphism. The frequencies of the AA (8.84\%) and GG (30.79\%) genotypes of Tth $111 \mathrm{I}$ were higher, and that of the AG genotype was lower (60.37\%), in the asthma patients compared to that seen in healthy controls $(5.00,26.67$, and $68.33 \%$, respectively). On the other hand, asthma patients showed higher frequencies of the AA genotype (78.05\%) of N363S, and lower
\end{abstract}


frequencies of the $\mathrm{AG}$ and $\mathrm{GG}$ genotypes (15.55 and 6.40\%), compared to healthy volunteers $(71.67,18.33$, and $10.00 \%$, respectively). Neither of these differences were found to be statistically significant. Moreover, we observed no significant differences in the genotype or allele frequencies of the BclI and ER22/23EK SNPs between the patient and control groups. In conclusion, SNPs in $\mathrm{NR} 3 \mathrm{Cl}$ were not significantly associated with asthma in patients from the Henan Province. Patients showed higher frequencies of the AA and GG genotypes of Tth111I and the AA genotype of the N363S SNP compared to healthy volunteers, although these differences were not significant.

Key words: NR3C1; Polymorphism; Tth111I; BclI; ER22/23EK; N363S; Asthma

\section{INTRODUCTION}

Asthma is a serious global health problem affecting people of all ages (Bateman et al., 2008). The constant deterioration in environmental quality, specifically the increase in air pollution and haze in the Henan province, has resulted in a drastic increase in the incidence of asthma.

Glucocorticosteroids (GCs) are commonly used in the treatment of asthma as key elements of complex therapy. However, the biological actions of GCs are complicated, and their effects are determined individually; therefore, some patients can have side effects despite the use of low doses of GCs, while others show no such effects even with high doses of GCs. Accordingly, a wide range of doses is used to treat and control asthma. Approximately 2.3 and $6.6 \%$ of a healthy population is resistant and sensitive to GCs, respectively (Lamberts et al., 1996; van der Velden, 1998; Ito et al., 2006; Adcock et al., 2008). However, recent studies have shown a considerable decrease in the efficacy of GCs in treating asthma, because of occurrence of mutations and single nucleotide polymorphisms (SNP) in NR3C1. These mutations induce a decrease in the expression of GR as well as excessive production of transcription factors, which in turn weakens the binding ability of GCs to DNA and their ligands (Luisi et al., 1991; Chanez et al., 2000; DeRijk et al., 2002; Kino et al., 2003; Leung and Bloom, 2003).

Previous studies have indicated that polymorphisms in the $G R$ gene could play a major role in the pathogenesis of asthma and the response of asthmatic patients to GC treatment (Ito et al., 2006). Four SNPs in the GR gene that are responsible for various disorders (Tth111I, $B c l$ I, ER22/23EK, and N363S) have also been reported to influence GR-sensitivity.

Tth $111 \mathrm{I}$ is a restriction fragment length polymorphism (RFLP) that is coupled with the ER22/23EK SNP (rs6189 and rs6190) (Detera-Wadleigh et al., 1991; Rosmond et al., 2000; DeRijk and de Kloet, 2008; Nicolaides et al., 2010; Panek et al., 2013a). The C/G SNP in $B c l$ (rs41423247) is associated with increased cortisol suppression (van Rossum et al., 2003; Stevens et al., 2004), while ER22/23EK (rs6189 and rs6190) (Koper et al., 1997) is believed to be associated with decreased GR sensitivity (van Rossum et al., 2002, 2004). On the other hand, the N363S A/G SNP (rs6195) affects the degree of phosphorylation of GR, via increased transactivation of gene coding, as well as increased cortisol suppression and insulin response (Koper et al., 1997; Huizenga et al., 1998).

In this study, we investigated the effect of SNPs of Tth111I, BclI, ER22/23EK, and N363S SNPs in NR3C1 on TGF-b1 mRNA expression in asthmatic patients in the Henan 
province of China, in order to identify the molecular diagnostic methods and anti-inflammatory drugs for asthma therapy based on the regional incidence of this disease.

\section{MATERIAL AND METHODS}

\section{Patients}

Three hundred and twenty-eight patients (212 males and 116 females; age: 18-65; average age: $43.37 \pm 20.67)$ diagnosed with asthma, based on the guidelines of the Global Initiative for Asthma (GINA) report (Bousquet, 2000), between February 1, 2005 and October 31,2011 by two doctors (with $>20$ years of experience) affiliated to the Respiratory and Critical Care Medicine department of the First Affiliated Hospital of Zhengzhou University were recruited to this study. The patient group was composed of 76 patients with intermittent asthma, 130 with mildly continuous asthma, 100 with moderately continuous asthma, and 22 with severely continuous asthma. Patients were selected based on a total immunoglobulin E (IgE) count $>0.2 \mathrm{IU} / \mathrm{L}$. The control group was composed of 60 healthy volunteers ( 31 males and 29 females; age: $20-65$; average age: $43.91 \pm 19.64$ ).

None of the patients or volunteers had any family history of asthma or any other disease, including lung disease (chronic obstructive pulmonary disease or pulmonary fibrosis), allergic inflammations (allergic rhinitis, atopic dermatitis, allergic purpura), diabetes, nephrotic disease, systemic lupus erythematosus, or psoriasis. Patients with asthma who were treated with rifampicin, phenobarbital, phenytoin, or ephedrine, or those with infection-induced asthma were not included in this study.

Informed consent was obtained from all patients and volunteers. This study was approved by the medical ethics committee of the First Affiliated Hospital of Zhengzhou University.

\section{DNA isolation}

Venal blood samples were collected from all patients and volunteers in EDTA(Thermo Fisher Scientific, Waltham, MA, USA) anticoagulant tubes. Genomic DNA was isolated using the TGuide M16 DNA extraction kit (Tiangen Biotech Co., Ltd., Beijing, China) according to the manufacturer instructions, and stored at $-20^{\circ} \mathrm{C}$ until further use.

\section{Genotyping the Tth111I, BclI, ER22/23EK, and N363S polymorphisms in NR3C1}

The genotypes of the Tth111I, BclI, ER22/23EK and N363S SNPs were identified by the TaqMan allelic discrimination assay (Thermo Fisher Scientific), designed using the Assay-by-Design service (Applied Biosystems, Foster City, CA, USA). The primer sequences, incubation temperatures, and restriction enzymes used to amplify the Tth $111 \mathrm{I}, B c l \mathrm{I}$, ER22/23EK, and N363S SNPs, as well as the resultant sequence lengths, are summarized in Table 1. The Tth111I, BclI, ER22/23EK, and N363S polymorphisms were exponentially amplified according to the PCR system detailed in Table 2.

The PCR mixture was composed of $2 \mu \mathrm{L} 5 \mathrm{ng}$ genomic DNA, $200 \mathrm{nM}$ probe, $0.9 \mu \mathrm{M}$ primers, and 2X Taqman PCR master mix (ABgene; Thermo Fisher Scientific). The DNA fragments were identified by melting curve analysis (Panek et al., 2013b), and the fragments of interest were genotyped by restriction fragment length polymorphism (RFLP) using the 
LightScanner High Sensitivity Master Mix (Idaho Technology, Salt Lake City, UT, USA). The RFLP products were separated by electrophoresis on an $8 \%$ polyacrylamide gel, and stained with ethidium bromide for observation under a UV light (Pharmacia Biotech ImageMaster VDS; BioSurplus, Inc., San Diego, CA, USA). Typical homozygotes and heterozygotes were sequenced and used as internal controls.

Table 1. Primer sequences, incubation temperatures, and restriction enzymes used to genotype the Tth111I, $B c l$ I, ER22/23EK, and N363S single nucleotide polymorphisms.

\begin{tabular}{|c|c|c|c|c|}
\hline & Forward primer & Reverse primer & Incubation temperature $\left({ }^{\circ} \mathrm{C}\right)$ & Restriction enzyme \\
\hline Tth111I & 5'-GGATGAATCCCTATCTGAGTG-3' & 5'-GGCCACAACAATAACCCAGTA-3' & 37 & PsyI \\
\hline$B c l \mathrm{I}$ & 5'-GAGAAATTCACCCCTACCAAC-3' & 5'-AGAGCCCTATTCTTCAAACTG-3' & 37 & $B c l \mathrm{I}$ \\
\hline ER22/23EK & 5'-TGCATTCGGAGTTAACTAAAA-3' & 5'-ATCCCAGGTCATTTCCCATCA-3' & 37 & $M n l \mathrm{I}$ \\
\hline N363S & 5'-CCAGTAATGTAACACTGCCCC-3' & 5'-TTCGACCAGGGGAAGTTCAGA-3' & 65 & TasI \\
\hline
\end{tabular}

Table 2. Polymerase chain reaction amplification system.

\begin{tabular}{l|c|c|c}
\hline Step & Temperature $\left({ }^{\circ} \mathrm{C}\right)$ & Time & Cycle number \\
\hline Pre-denaturation & 95 & $15 \mathrm{~min}$ & \\
\hline Denaturation & 95 & $15 \mathrm{~s}$ & 40 cycles \\
\hline Annealing & 60 & $60 \mathrm{~s}$ & \\
\hline Extension & 60 & $60 \mathrm{~s}$ & 1 cycle \\
\hline Terminal extension & 72 & $7 \mathrm{~min}$ & \\
\hline Storage & 4 & $\rightarrow \infty$ & \\
\hline
\end{tabular}

\section{Statistical analysis}

SPSS 19.0 (IBM, Armonk, NY, USA) was used to analyze the data. The genotype and allele frequencies of the GR SNPs were analyzed using the chi-square test. The conformance of the genotypes and alleles of all SNPs with the Hardy-Weinberg equilibrium (HWE) was confirmed using the online calculator developed by Michael H. Court. Differences with P values $<0.05$ were considered to be statistically significant.

\section{RESULTS}

\section{Genotype and single polymorphic allele frequencies of the NR3C1 SNPs}

The 4 SNP sites were in accordance with the HWE in both the case and control groups $(\mathrm{P}>0.05)$, indicating the representativeness of the sample subset. The genotype and single polymorphic allele frequencies of the Tth111I, BclI, ER22/23EK, and N363S SNPs in NR3Cl are summarized in Table 3. We observed no significant differences in the genotype and allele frequencies of the Tth111I, BclI, ER22/23EK, and N363S SNPs between the cases and controls. However, the frequencies of the AA and GG genotypes were higher, and that of the AG genotype was lower, in the asthma patients than that in the healthy volunteers. Specifically, a greater percentage of asthma patients expressed the AA frequency compared to the healthy volunteers, while the genotype frequencies of AG and GG were lower in the asthma patients. 
Table 3. Frequencies of the genotypes and single polymorphic alleles of the Tth111I, BclI, ER22/23EK, and N363S single nucleotide polymorphisms.

\begin{tabular}{|c|c|c|c|c|c|c|c|}
\hline \multicolumn{3}{|l|}{ NR3CI SNP } & \multicolumn{2}{|c|}{ Cases group $(\mathrm{N}=328)$} & \multicolumn{2}{|c|}{ Control group $(\mathrm{N}=60)(\%)$} & \multirow[t]{2}{*}{$\mathrm{P}$} \\
\hline & & & $\mathrm{N}$ & Frequency (\%) & $\mathrm{N}$ & Frequency (\%) & \\
\hline \multirow[t]{5}{*}{ Tth111I } & \multirow[t]{3}{*}{ Genotype } & $\mathrm{AA}$ & 29 & 8.84 & 3 & 5.00 & \multirow[t]{5}{*}{0.089} \\
\hline & & $\mathrm{AG}$ & 198 & 60.37 & 41 & 68.33 & \\
\hline & & GG & 101 & 30.79 & 16 & 26.67 & \\
\hline & \multirow[t]{2}{*}{ Allele } & $\mathrm{A}$ & 256 & 39.02 & 47 & 39.17 & \\
\hline & & $\mathrm{G}$ & 400 & 60.98 & 73 & 60.83 & \\
\hline \multirow[t]{5}{*}{$B c l$ I } & \multirow[t]{3}{*}{ Genotype } & $\mathrm{CC}$ & 20 & 6.10 & 3 & 5.00 & \multirow[t]{5}{*}{0.532} \\
\hline & & CG & 90 & 27.44 & 15 & 25.00 & \\
\hline & & GG & 218 & 66.46 & 42 & 70.00 & \\
\hline & \multirow[t]{2}{*}{ Allele } & $\mathrm{C}$ & 130 & 19.82 & 21 & 17.50 & \\
\hline & & G & 526 & 80.18 & 99 & 82.50 & \\
\hline \multirow[t]{5}{*}{ ER22/23EK } & \multirow[t]{3}{*}{ Genotype } & AA & 0 & 0.00 & 0 & 0.00 & \multirow[t]{5}{*}{0.806} \\
\hline & & AG & 15 & 4.57 & 3 & 5.00 & \\
\hline & & GG & 313 & 95.43 & 57 & 95.00 & \\
\hline & \multirow{2}{*}{ Allele } & $\mathrm{A}$ & 15 & 2.29 & 3 & 2.50 & \\
\hline & & G & 641 & 97.71 & 117 & 97.50 & \\
\hline \multirow[t]{5}{*}{ N363S } & \multirow[t]{3}{*}{ Genotype } & AA & 256 & 78.05 & 43 & 71.67 & \multirow[t]{5}{*}{0.103} \\
\hline & & $\mathrm{AG}$ & 51 & 15.55 & 11 & 18.33 & \\
\hline & & GG & 21 & 6.40 & 6 & 10.00 & \\
\hline & \multirow[t]{2}{*}{ Allele } & A & 563 & 85.82 & 97 & 80.83 & \\
\hline & & $\mathrm{G}$ & 93 & 14.18 & 23 & 19.17 & \\
\hline
\end{tabular}

\section{DISCUSSION}

Asthma is a complex disease, incorporating the secretion of several substances, such as cytokines, by various cells. Asthma is a chronic inflammatory disease of the respiratory system; this disease is determined by a number of factors, including interactions between hereditary and environmental factors, resulting in the development of various complications such as bronchial hyper-responsiveness, recurrent episodes of wheezing, cough, and dyspnea (Panek et al., 2013a,b).

It is important to determine the level of hypersensitivity of a patient to GCs in clinical practice. Asthma is induced in the presence of a high concentration of cortisol in the blood, characterized by a high 24-h excretion of free cortisol, but without the symptoms of Cushing's syndrome.

Resistance to GCs is related to mutations in $N R 3 C l$, which induce changes in the amino acid content in the structural receptor regions, whose functional domains play important roles in the biological action of related proteins. Asthmatic patients showing a lack of or very slight response to GCs have been shown to express normal levels of cortisol (Lipsett et al., 1985; DeRijk et al., 2002; Kino et al., 2003; Bray and Cotton, 2003; Adcock et al., 2008).

Patients that received inefficient GC treatment displayed an increase in the density of complement receptors on monocytes, while the expression of GR did not change in these patients compared to that in patients who were sensitive to GCs (Carmichael et al., 1981). On the other hand, patients that did not receive GC treatment showed activation of the p38 mitogen-activated protein kinase (p38MAP) due to the chronic inflammatory effect of cytokines interleukin (IL)-2 and IL-4. The affinity of GR to GCs is also influenced by the activity of other kinases, including the mitogen-activated protein kinase (MAPK). Patients 
displaying low sensitivity to GCs have been reported to display increased cellular activity of the c-Jun N-terminal kinase (JNK). These findings indicated that phosphorylation pathways dependent on p38MAPK and JNK inhibited GC activity (Barnes, 2006).

Therefore, we attempted to elucidate the significance of the effect of NR3C1 SNPs in asthma, but observed no significant differences in the genotype and allele frequencies between asthma patients and healthy individuals in this study. However, asthma patients showed higher frequencies of the AA or GG genotype, and lower frequencies of the AG genotype, compared to healthy volunteers. Although this difference was not statistically significant, the higher incidence of the AA and GG genotypes indicated a possible relationship between the Tth111I SNP and asthma incidence.

Previous studies (van Rossum and Lamberts, 2004; De Iudicibus et al., 2011; Panek et al., 2013a) reported an association between the Tth111I SNP and increased cortisol level in the blood; additionally, these studies reported a decrease in the cortisol secretion following the administration of $1 \mathrm{mg}$ dexamethasone (DEX). Additionally, carriers of the Tth111I SNP who also express the ER22/23EK SNP have been shown to induce resistance to GCs and show a normal metabolic profile (Van Rossum et al., 2004; Nicolaides et al., 2010; Panek et al., 2012a). Other studies have confirmed that the N363S SNP imparts the GC-GR complex with an increased ability to transactivate its target genes (Huizenga et al., 1998; Panek et al., 2012a,b). In this study, patients with asthma presented higher frequencies of the AA variant, and lower frequencies of the AG and GG variants, of the N363S SNP, compared to the healthy volunteers, which was consistent with the results of previous studies (Huizenga et al., 1998; Panek et al., 2012a,b, 2013a). Some reports have also indicated that the AG or GG variants at codon 363 of NR3C1 are correlated with increased anti-inflammatory effects during GC treatment, and lower risk of uncontrolled asthma; however, this effect was not significant in this study. These differences could be attributed to the small sample size or the regional limitation.

In conclusion, the Tth111I and N363S SNPs of NR3C1 could be related to asthma in a Chinese population specific to the Hebei province. Patient-specific molecular diagnostic tests, and anti-inflammatory drugs and targeted therapy for the treatment of asthma must be identified and confirmed in future investigations.

\section{Conflicts of interest}

The authors declare no conflict of interest.

\section{REFERENCES}

Adcock IM, Ford PA, Bhavsar P, Ahmad T, et al. (2008). Steroid resistance in asthma: mechanisms and treatment options. Curr. Allergy Asthma Rep. 8: 171-178.http://dx.doi.org/10.1007/s11882-008-0028-4

Bousquet J (2000). Global initiative for asthma (GINA) and its objectives. Clin. Exp. Allergy 30 (Suppl 1): 2-5. http:// dx.doi.org/10.1046/j.1365-2222.2000.00088.x

Bateman ED, Hurd SS, Barnes PJ, Bousquet J, et al. (2008). Global strategy for asthma management and prevention: GINA executive summary. Eur. Respir. J. 31: 143-178. http://dx.doi.org/10.1183/09031936.00138707

Barnes PJ (2006). Corticosteroid effects on cell signalling. Eur. Respir. J. 27: 413-426. http://dx.doi.org/10.1183/09031 $\underline{936.06 .00125404}$

Bray PJ and Cotton RG (2003). Variations of the human glucocorticoid receptor gene (NR3C1): pathological and in vitro mutations and polymorphisms. Hum. Mutat. 21: 557-568. http://dx.doi.org/10.1002/humu.10213

Carmichael J, Paterson IC, Diaz P, Crompton GK, et al. (1981). Corticosteroid resistance in chronic asthma. Br. Med. J. (Clin. Res. Ed.) 282: 1419-1422. http://dx.doi.org/10.1136/bmj.282.6274.1419 
Chanez P, Vachier I, Michel FB, Bousquet J, et al. (2000). Corticosteroid therapy of asthma. Presse Med. 29: 1469-1478. De Iudicibus S, Franca R, Martelossi S, Ventura A, et al. (2011). Molecular mechanism of glucocorticoid resistance in inflammatory bowel disease. World J. Gastroenterol. 17: 1095-1108. http://dx.doi.org/10.3748/wjg.v17.i9.1095

DeRijk RH, Schaaf M and de Kloet ER (2002). Glucocorticoid receptor variants: clinical implications. J. Steroid Biochem. Mol. Biol. 81: 103-122. http://dx.doi.org/10.1016/S0960-0760(02)00062-6

DeRijk RH and de Kloet ER (2008). Corticosteroid receptor polymorphisms: determinants of vulnerability and resilience. Eur. J. Pharmacol. 583: 303-311.http://dx.doi.org/10.1016/j.ejphar.2007.11.072

Detera-Wadleigh SD, Encio IJ, Rollins DY, Coffman D, et al. (1991). A TthIII1 polymorphism on the 5' flanking region of the glucocorticoid receptor gene (GRL). Nucleic Acids Res. 19: 1960. http://dx.doi.org/10.1093/nar/19.8.1960-a

Huizenga NA, Koper JW, De Lange P, Pols HA, et al. (1998). A polymorphism in the glucocorticoid receptor gene may be associated with and increased sensitivity to glucocorticoids in vivo. J. Clin. Endocrinol. Metab. 83: 144-151.

Ito K, Chung KF and Adcock IM (2006). Update on glucocorticoid action and resistance. J. Allergy Clin. Immunol. 117: 522-543.http://dx.doi.org/10.1016/j.jaci.2006.01.032

Kino T, De Martino MU, Charmandari E, Mirani M, et al. (2003). Tissue glucocorticoid resistance/hypersensitivity syndromes. J. Steroid Biochem. Mol. Biol. 85: 457-467.http://dx.doi.org/10.1016/S0960-0760(03)00218-8

Koper JW, Stolk RP, de Lange P, Huizenga NA, et al. (1997). Lack of association between five polymorphisms in the human glucocorticoid receptor gene and glucocorticoid resistance. Hum. Genet. 99: 663-668. http://dx.doi. org/10.1007/s004390050425

Lamberts SW, Huizenga AT, de Lange P, de Jong FH, et al. (1996). Clinical aspects of glucocorticoid sensitivity. Steroids 61: 157-160. http://dx.doi.org/10.1016/0039-128X(96)00005-0

Leung DY and Bloom JW (2003). Update on glucocorticoid action and resistance. J. Allergy Clin. Immunol. 111: 3-22, quiz 23. http://dx.doi.org/10.1067/mai.2003.97

Lipsett MB, Chrousos GP, Tomita M, Brandon DD, et al. (1985). The defective glucocorticoid receptor in man and nonhuman primates. Recent Prog. Horm. Res. 41: 199-247.

Luisi BF, Xu WX, Otwinowski Z, Freedman LP, et al. (1991). Crystallographic analysis of the interaction of the glucocorticoid receptor with DNA. Nature 352: 497-505.http://dx.doi.org/10.1038/352497a0

Nicolaides NC, Galata Z, Kino T, Chrousos GP, et al. (2010). The human glucocorticoid receptor: molecular basis of biologic function. Steroids 75: 1-12.http://dx.doi.org/10.1016/j.steroids.2009.09.002

Panek M, Pietras T, Antczak A, Fabijan A, et al. (2012a). The N363S and I559N single nucleotide polymorphisms of the h-GR/NR3C1 gene in patients with bronchial asthma. Int. J. Mol. Med. 30: 142-150.

Panek M, Pietras T, Antczak A, Górski P, et al. (2012b). The role of functional single nucleotide polymorphisms of the human glucocorticoid receptor gene NR3C1 in Polish patients with bronchial asthma. Mol. Biol. Rep. 39: 4749-4757. http://dx.doi.org/10.1007/s11033-011-1267-3

Panek M, Pietras T, Fabijan A, Miłanowski M, et al. (2013a). Effect of glucocorticoid receptor gene polymorphisms on asthma phenotypes. Exp. Ther. Med. 5: 572-580.

Panek M, Pietras T, Szemraj J, Fabijan A, et al. (2013b). Identification and association of TGF $\beta-1$ expression in patients with asthma in a Polish population - Lodz metropolitan area study. Int. J. Biochem. Mol. Biol. 4: 67-74.

Rosmond R, Chagnon YC, Chagnon M, Pérusse L, et al. (2000). A polymorphism of the 5 '-flanking region of the glucocorticoid receptor gene locus is associated with basal cortisol secretion in men. Metabolism 49: 1197-1199. http://dx.doi.org/10.1053/meta.2000.7712

Stevens A, Ray DW, Zeggini E, John S, et al. (2004). Glucocorticoid sensitivity is determined by a specific glucocorticoid receptor haplotype. J. Clin. Endocrinol. Metab. 89: 892-897.http://dx.doi.org/10.1210/jc.2003-031235

van der Velden VH (1998). Glucocorticoids: mechanisms of action and anti-inflammatory potential in asthma. Mediators Inflamm. 7: 229-237.http://dx.doi.org/10.1080/09629359890910

van Rossum EF and Lamberts SW (2004). Polymorphisms in the glucocorticoid receptor gene and their associations with metabolic parameters and body composition. Recent Prog. Horm. Res. 59: 333-357. http://dx.doi.org/10.1210/ rp.59.1.333

van Rossum EF, Koper JW, Huizenga NA, Uitterlinden AG, et al. (2002). A polymorphism in the glucocorticoid receptor gene, which decreases sensitivity to glucocorticoids in vivo, is associated with low insulin and cholesterol levels. Diabetes 51: 3128-3134. http://dx.doi.org/10.2337/diabetes.51.10.3128

van Rossum EF, Koper JW, van den Beld AW, Uitterlinden AG, et al. (2003). Identification of the BclI polymorphism in the glucocorticoid receptor gene: association with sensitivity to glucocorticoids in vivo and body mass index. Clin. Endocrinol. 59: 585-592.http://dx.doi.org/10.1046/j.1365-2265.2003.01888.x

van Rossum EF, Roks PH, de Jong FH, Brinkmann AO, et al. (2004). Characterization of a promoter polymorphism in the glucocorticoid receptor gene and its relationship to three other polymorphisms. Clin. Endocrinol. 61: 573-581. http:// dx.doi.org/10.1111/j.1365-2265.2004.02132.x 